\title{
41VN63: A Late Archaic-Woodland Period Site in the Upper Sabine River Basin, Van Zandt County, Texas
}

Timothy K. Perttula

Heritage Research Center, Stephen F. Austin State University

Bob D. Skiles

Julian A. Sitters

Texas Historical Commission

Follow this and additional works at: https://scholarworks.sfasu.edu/ita

Part of the American Material Culture Commons, Archaeological Anthropology Commons, Environmental Studies Commons, Other American Studies Commons, Other Arts and Humanities Commons, Other History of Art, Architecture, and Archaeology Commons, and the United States History Commons

Tell us how this article helped you.

This Article is brought to you for free and open access by the Center for Regional Heritage Research at SFA ScholarWorks. It has been accepted for inclusion in Index of Texas Archaeology: Open Access Gray Literature from the Lone Star State by an authorized editor of SFA ScholarWorks. For more information, please contact cdsscholarworks@sfasu.edu. 


\section{VN63: A Late Archaic-Woodland Period Site in the Upper Sabine River Basin, Van Zandt County, Texas}

\section{Creative Commons License}

\section{(c) (i) (9)}

This work is licensed under a Creative Commons Attribution-NonCommercial 4.0 International License 


\title{
41VN63: A Late Archaic-Woodland Period Site in the Upper Sabine River Basin, Van Zandt County, Texas
}

\author{
Timothy K. Perttula, Bob D. Skiles, and Julian A. Sitters
}

\section{Introduction}

Site 41VN63 is a multiple component Late Archaic (circa [ca.] 5000-2500 years B.P.) and Woodland period (ca. 2500-1150 years B.P.) site on an upland landform in the upper Sabine River basin (Figure 1). The site was recorded by James Malone (1972) during the archaeological survey of then-proposed Mineola Reservoir on the Sabine River; the reservoir has not been built.

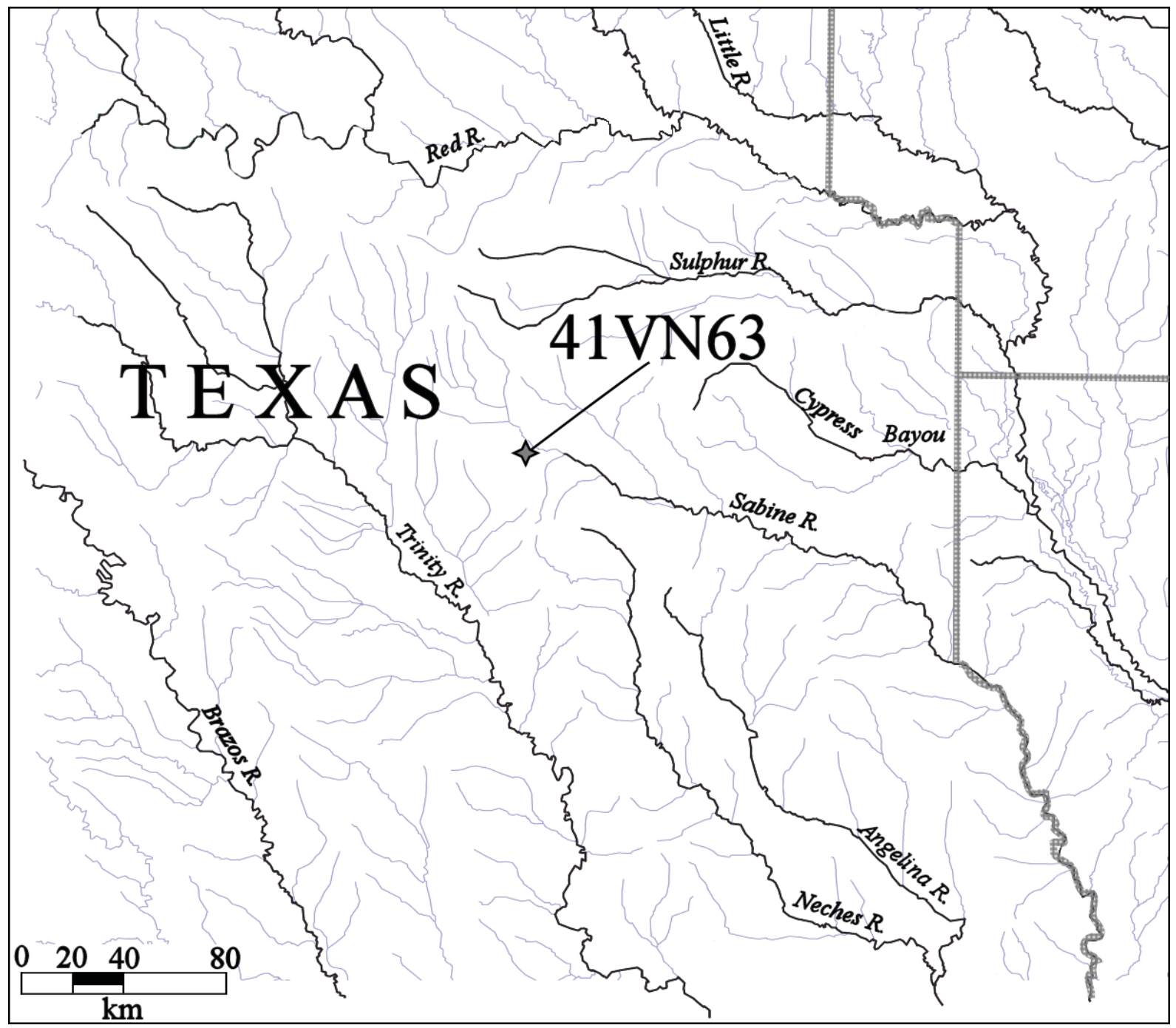

Figure 1. The general location of 41VN63 in East Texas. 
Malone described the site in 1971 as being located on an upland ridge on the southeast side of Caney Creek, and covered a $20 \times 50 \mathrm{~m}$ area. He noted and/or collected from the site surface chert, quartzite, and petrified wood lithic debris $(n=28)$ and cores $(n=11)$ (Malone 1972:Figure 11). Malone also mentioned finding flake tools as well as plain pottery sherds at the site, but no such artifacts were mentioned in Malone's (1972) tabulations. This collection has yet to be examined at the Texas Archeological Research Laboratory at The University of Texas at Austin.

Shortly thereafter, Bob D. Skiles learned of the site and, with the permission of the landowner, conducted surface collections there on several occasions over the next two years, and recorded the site as GS-1 in his site recording system. In the late 1980s, Skiles loaned Perttula the artifacts he had collected from the site, and they were studied and documented at that time. Now, this many years later, the results of those analyses are provided in this article.

\section{Site Setting}

The site is on the northern end of an upland ridge landform overlooking Caney Creek, a northernflowing tributary to the Sabine River, to the north as well as the southern edge of the Sabine River floodplain, several kilometers from the river itself. The landform has sandy loam sediments.

Skiles observed in the early 1970s when he was conducting surface collections there, that the site had a high concentration of lithic artifacts in a small area (ca. $20 \mathrm{~m}$ in diameter) of darkly-stained midden sediments. Artifacts were primarily eroding out of the midden deposits in deep gullies on the western edge of the landform. The midden deposits extended from the bottom of a shallow plow zone (ca. $20 \mathrm{~cm}$ thick) to about $1 \mathrm{~m}$ below the surface (bs); the midden was probably $70-80 \mathrm{~cm}$ in thickness. The upland soils on upland ridge landforms (particularly on ridge projections fringing the Sabine River floodplain) were light tan sandy loams about 50-100 cm in thickness, overlying a dense red clay B-horizon. The site was also plowed at that time, and thus surface visibility was good for collecting purposes.

\section{Artifact Assemblage}

The artifact assemblage amassed at 41VN63 by Skiles includes dart points $(\mathrm{n}=66)$ and dart point fragments $(n=11)$, arrow points $(n=4)$, and thin or thick biface fragments $(n=12)$ (Table 1). A few of the thin bifaces have smoothed or ground lateral edges, suggesting that they had been hafted tools, probably knives. Contracting stem Gary dart points of Woodland period age (see below) are by far the most common dart point type in the assemblage, with only a few other dart points of either Woodland ( $\mathrm{n}=2$, Kent) or Late Archaic ( $n=3$, Trinity and Yarbrough) period ages.

Thickness and stem width measurements of the Gary dart points from 41VN63 indicate that they have a mean thickness of $6.89 \mathrm{~mm}$ and a mean stem width of $14.08 \mathrm{~mm}$. These values are consistent with the Gary, var. Camden dart point (see Schambach 1982:Table 7-4; Leith 2014:Table 1), the latest of the defined Gary varieties. This variety of Gary point appears to have been made and used in the region between ca. A.D. 250-750 (see Schambach 1982), and it is likely that the main occupation of 41VN63 took place at that time.

The occurrence of Friley and Catahoula points at 41VN63 indicate that the site was also used from ca. A.D. 700-800, as these are the earliest arrow point forms - along with Steiner arrow points - known in East Texas (Shafer and Walters 2010:128). Only 25 percent of these Late Woodland period arrow points are made from the locally available grayish-white quartzite raw material.

Many of the artifacts from 41VN63 were made from a coarse grayish-white quartzite (see Table 1), about 64.5 percent; this quartzite turned pink when heat-treated. There is a quarry recorded by Malone (1972) at 41VN39 of this very distinctive quartzite raw material about $10 \mathrm{~km}$ to the west-southwest of 
Table 1. Artifacts from 41VN63 in the Skiles collection.

\begin{tabular}{|c|c|c|c|c|c|c|}
\hline Tool type & Gray-white QTZ & Ogallala QTZ & Chert & FS & PW & $\mathrm{N}$ \\
\hline Gary dart point & 42 & 18 & - & 1 & - & 61 \\
\hline Kent dart point & 2 & - & - & - & - & 2 \\
\hline $\begin{array}{l}\text { Yarbrough dart } \\
\text { point }\end{array}$ & - & 2 & - & - & - & 2 \\
\hline Trinity dart point & - & - & - & - & 1 & 1 \\
\hline Dart point tips & 7 & 3 & - & - & - & 10 \\
\hline $\begin{array}{l}\text { Dart point mid- } \\
\text { section }\end{array}$ & - & - & 1 & - & - & 1 \\
\hline Friley arrow point & - & 2 & - & - & 1 & 3 \\
\hline $\begin{array}{l}\text { Catahoula arrow } \\
\text { point }\end{array}$ & 1 & - & - & - & - & 1 \\
\hline Thick biface & 2 & - & - & - & - & 2 \\
\hline $\begin{array}{l}\text { Thin biface, not } \\
\text { hafted }\end{array}$ & 5 & - & - & - & - & 5 \\
\hline Thin biface, hafted & 1 & 4 & - & - & - & 5 \\
\hline Totals & 60 & 29 & 1 & 1 & 1 & 93 \\
\hline
\end{tabular}

QTZ=quartzite; FS=ferruginous sandstone; $P W=$ petrified wood

41VN63 on Mill Creek, another northward-flowing tributary to the Sabine River. According to Malone (1972:32), the quarry covers between 3-4 acres of an upland landform, manifested as outcrops of large boulders (Malone 1972:Figure 13) with "partially decorticated cores, as well as numerous flakes." Other raw materials used in tool manufacture at this site include fine-grained Ogallala quartzite (31.2 percent), chert (1.1 percent), ferruginous sandstone (1.1 percent), and petrified wood (1.1 percent), likely also locally available, probably in stream gravels.

Almost 70 percent of the Gary dart points from 41VN63 are made on the gray-white quartzite (see Table 1); 70 percent of the dart point tips are also made from this material. At the Yarbrough site (41VN6, see Johnson 1962) a few miles east of 41VN63, only about 4 percent of the dart points are made from this distinctive quartzite, mostly having been heat-treated. This includes 5.2 percent of the Gary points $(n=328), 2.1$ percent of the Wells points $(n=47), 5.3$ percent of the Marshall points $(n=19), 15.2$ percent of the Ellis points $(n=33), 6.0$ percent of the Edgewood points $(n=50)$, and 20.0 percent of the Wesley points $(n=5)$; none of the arrow points $(n=9)$ were made from this white/pink quartzite. The age of the dart points made from this quartzite certainly suggest that this material was primarily utilized in Late Archaic and Woodland period times, as is the case at 41VN63. At another site (unrecorded) on the Robert L. Richey property on the Sabine River a few miles west of 41VN63, the grayish-white quartzite raw material occurs on 61.5 percent of the small lithic debris sample $(n=8)$ (see Perttula and Richey, this volume). The few diagnostic artifacts from this site are decorated ceramic sherds that likely date from ca. A.D. 900-1200, indicating the continued use of this quartzite raw material in ancestral Caddo times.

Malone had reported plain pottery on the site form for the site when he identified and recorded it in April 1971; what kind of plain pottery is not mentioned. However, Malone (1972) is not helpful in determining if sherds were recovered from $41 \mathrm{VN} 63$, or what their character is, because Malone (1972:41-46 and Figure 19) chose to discuss in aggregate the ceramic sherds found in 55 sites in the survey of proposed Mineola Reservoir, not by individual site; no site by site inventory is provided in 
Malone (1972). Skiles did not find pottery sherds during his surface collecting at 41VN63 a few years later. When Skiles asked the landowner if he had ever found pottery there, he said he had not during the few years he had been living there and using the site as a garden place. He did tell Skiles that he had regularly found projectile points at the site.

\section{Summary and Conclusions}

41VN63 is a Late Archaic and Woodland period site on an upland ridge projection along a tributary to the Sabine River in the proposed Lake Mineola project area. The site was recorded by James M. Malone in April 1971, and at that time he found cores and lithic debris there; flake tools and plain pottery were mentioned as being found at $41 \mathrm{VN} 63$ on the site form, but not in the published report on the archaeological survey findings (Malone 1972).

Bob D. Skiles began surface collection investigations at 41VN63 in 1972, after being given permission to work at the site by the landowner. The collections were analyzed in the late 1980s, and the results provided in this article. 41VN63 has a high density of small Gary, var. Camden dart points, indicative of a primary occupation by ancestral Caddo peoples between ca. A.D. 250-750. The other recovered projectile points in the assemblage also suggest that the site was used to a much more limited extent during some part of the Late Archaic period (ca. 3050-550 years B.C.) and the Late Woodland (ca. A.D. 700-800) period. The most distinctive aspect of the artifact collection from 41VN63 is the heavy use of a coarse-grained grayish-white quartzite for manufacture of the Gary dart points and several of the bifaces; about 70 percent of the Gary points are made of this raw material. This raw material is locally available in a boulder quarry (41VN39) only a few miles from 41VN63.

\section{Acknowledgments}

Lance Trask prepared Figure 1 for this article.

\section{References Cited}

Johnson, L., Jr.

1962 The Yarbrough and Miller Sites of Northeastern Texas, with a Preliminary Definition of the LaHarpe Aspect. Bulletin of the Texas Archeological Society 32:141-284.

Leith, L.

2014 Towards a Common Understanding: A Revision of Fourche Maline Chronology in Oklahoma. Caddo Archeology Journal 24:5-28.

Malone, J. M.

1972 Archaeological Reconnaissance at Proposed Mineola Reservoir. Archeological Survey Report No. 10. Texas Historical Survey Committee, Austin.

Schambach, F. F.

1982 An Outline of Fourche Maline Culture in Southwest Arkansas. In Arkansas Archeology in Review, edited by N. L. Trubowitz and M. D. Jeter, pp. 132-197. Research Series No. 15. Arkansas Archeological Survey, Fayetteville.

Shafer, H. and M. Walters

2010 The Browning Site (41SM195A) Lithics: Considering Patterns of Identity and Interaction Through Lithic Analysis. Bulletin of the Texas Archeological Society 81:127-151. 